\title{
Investigating the role of government trade policies and regulations on smuggling cosmetic products
}

\author{
Sahar Seifpoor ${ }^{*}$ and Reza Agha Mousa ${ }^{c}$
}

Department of Management and Accounting, Islamic Azad University, South Tehran Branch, Tehran, Iran

\section{H R O N I C L E}

Article history:

Received December 2, 2013

Accepted 8 May 2014

Available online

May 142014

Keywords:

Smuggling

Cosmetic

Tariff \begin{abstract}
A B S T R A C T
This paper investigates the effects of government trade policies as well as the rules and regulations on smuggling cosmetic products in Iran. The study considers the effects of five important factors including high tariffs and bureaucratic procedures, registration process, size and expire date, lack of accurate monitoring of distribution channels and government recent regulation failure on growth of smuggling cosmetic products in Iran. The proposed study uses structural equation modeling to examine the effects of these five components. The results indicate a positive and meaningful relationships between four variables including registration process $(\beta=0.84, \mathrm{P}$-value $=0.000)$, size and expire date $(\beta=0.86$, $\mathrm{P}$-value $=0.000)$, high rate of tariff $(\beta=0.88, \mathrm{P}$-value $=0.000)$ and government recent regulation failure $(\beta=0.97, \mathrm{P}$-value $=0.000$ ) on growth of smuggling cosmetic products in Iran. In addition, the study has detected a negative and meaningful relationship between lack of accurate monitoring of distribution channels and growth of smuggling cosmetic products in Iran $(\beta=-0.18, \mathrm{P}-\mathrm{value}=0.000)$.
\end{abstract}

\section{Introduction}

Smuggling is one of the common problems among all countries around the world. When it comes to smuggling human (Mountz, 2003, 2004; Hartnett \& Dawdy, 2013) and drugs (Decker \& Chapman, 2008; Benson \& Decker, 2010), most governments do their best to fight against it. However, when it comes to smuggling cosmetic products, there are not many expectations from governments since they have limited budgets and may not care about the consequences (Bhagwati \& Hansen, 1973). Every year, Iranian women spend approximately 2.1 billion dollars for cosmetic products, which is about $29 \%$ of middle cosmetic consumption. In other words, any Iranian woman aged 15-45 spends $7 \$$ per month for cosmetic stuff. Many Iranian women prefer to use brand products, which are subject to high rates of tariff and this motivates some people to smuggle these kinds of products. Fig. 1 shows

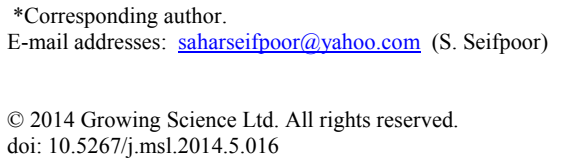


an increasing trend on smuggled products confiscated by the government of Iran over the period 2002-2012.

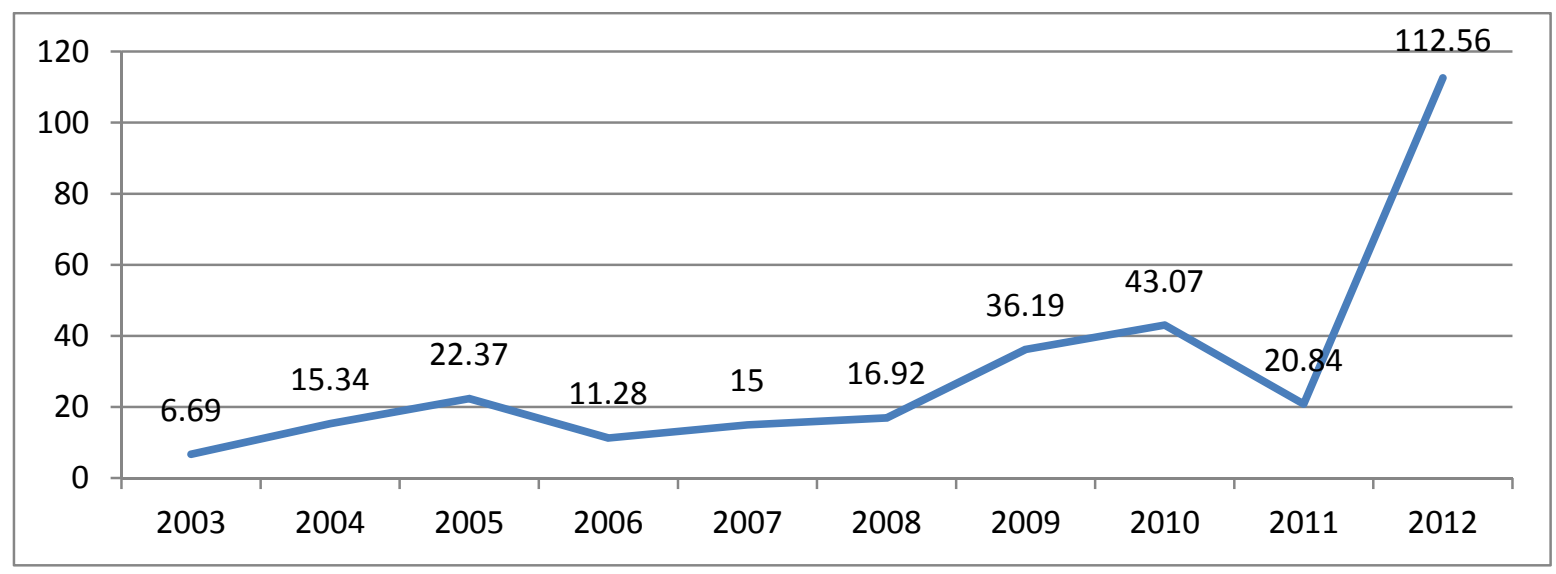

Fig. 1. Trend of confiscated smuggled cosmetic products

As we can observe from the results of Fig. 1, there is an increasing trend on confiscated smuggled cosmetic products. In other words, assuming not much change on custom security rules and regulations, we may conclude that demand for cosmetic products has been increased over the past few years. We may see similar patterns in other countries for smuggling other products, for instance, generic cigarettes lower price elasticity and diminish the effect of formal smuggling in United States (Goel, 2012). Farzanegan (2009) studied the causes and consequences of import/ export smuggling and estimated its relative size in Iran over the period 1970-2002. They applied Multiple IndicatorsMultiple Causes (MIMIC) modeling and trade mis-invoicing to calculate the latent variable of smuggling. They reported that the penalty rate for smuggling and the quality of economic and political institutions could reduce smuggling, while tariffs and black market could increase the incentives for illegal trade. More trade openness was associated with bigger illegal trade in the case of Iran. On average, they reported that smuggling in Iran was approximately $13 \%$ of total trade.

Martin and Panagariya (1984) provided a general model of smuggling capable of handling both the Bhagwati-Hansen kind of illegal trade through illegal entry points, and the Pitt kind of illegal trade through legal entry points by concentrating on the latter kind of trade. They considered the risk and uncertainty related to illegal activity, treated the real expenses of smuggling as a choice variable of the firm, and reported that smuggling, legal trade, and price disparity could coexist as in Pitt. They also explained that increased enforcement raises real per unit expenses of smuggling and the domestic price of importables but lowered both the absolute quantity and the share of illegal imports in total imports. Bruns et al. (2011) and Breuer and Kreuer (2012) explained different connections between informal and formal activities and specificities of localities, which people in the mentioned countries deploy when attempt to secure their livelihood. Xheneti et al. (2013) explained how the spatial, economic, institutional and sociocultural characteristics of a context overlap, dominate or recede at various points in time to facilitate/inhibit various forms of entrepreneurial behavior and to encourage the involvement of, or empower, different groups of people.

\section{The proposed study}

This paper investigates the effects of government trade policies as well as rules and regulations on smuggling cosmetic products in Iran. The study considers the effects of five important factors including high tariffs and bureaucratic procedures, registration process, size and expire date, lack of accurate monitoring of distribution channels and government recent regulation failure on growth of smuggling cosmetic products in Iran. The population of this study includes all people who live in city of Tehran, Iran. Therefore, the sample size is calculated as follows, 
$N=Z_{\alpha / 2}^{2} \frac{p \times q}{e^{2}}$,

where $N$ is the sample size, $p=1-q$ represents the probability, $z_{\alpha / 2}$ is CDF of normal distribution and finally $\varepsilon$ is the error term. For our study we assume $p=0.5, z_{\alpha / 2}=1.96$ and $e=0.05$, the number of sample size is calculated as $N=384$. The proposed study uses structural equation modeling to examine the effects of these five components. The study designed a questionnaire with 28 questions consists of five categories including high tariffs and bureaucratic procedures, registration process, size and expire date, lack of accurate monitoring of distribution channels and government recent regulation failure on growth of smuggling cosmetic products in Iran. Therefore, there are five hypotheses associated with the proposed study as follows,

1. High tariffs and bureaucratic procedures of cosmetic products influence on growth of smuggling cosmetic products in Iran.

2. Registration process of cosmetic products influence on growth of smuggling cosmetic products in Iran.

3. Size and expire date of cosmetic products influence on growth of smuggling cosmetic products in Iran.

4. Lack of accurate monitoring of distribution channels of cosmetic products influence on growth of smuggling cosmetic products in Iran.

5. Government recent regulation failure on growth of smuggling cosmetic products influence on growth of smuggling cosmetic products in Iran.

All questions of the survey have been arranged in Likert scale and Table 1 summarizes some basic statistics such as mean, standard deviation, etc.

Table 1

The summary of some basic statistics

\begin{tabular}{|c|c|c|c|c|c|c|}
\hline Variable & Min & Max & Skewness & C.R. & Kurtosis & C.R. \\
\hline n2 & 1.000 & 5.000 & -.341 & -1.898 & -.314 & -.874 \\
\hline $\mathrm{n} 1$ & 1.000 & 5.000 & -.055 & -.305 & -.708 & -1.971 \\
\hline $\operatorname{sh} 5$ & 1.000 & 5.000 & -.448 & -2.492 & -.280 & -.779 \\
\hline $\operatorname{sh} 4$ & 1.000 & 5.000 & -.133 & -.742 & -.208 & -.578 \\
\hline $\operatorname{sh} 3$ & 1.000 & 5.000 & .196 & 1.089 & -.664 & -1.849 \\
\hline $\operatorname{sh} 2$ & 1.000 & 5.000 & -.741 & -4.128 & .542 & 1.508 \\
\hline $\operatorname{sh} 1$ & 1.000 & 5.000 & -.211 & -1.173 & -.539 & -1.501 \\
\hline a4 & 1.000 & 5.000 & .218 & 1.215 & -.727 & -2.024 \\
\hline a3 & 1.000 & 5.000 & -.360 & -2.006 & -.409 & -1.139 \\
\hline a2 & 1.000 & 5.000 & -.150 & -.835 & -.196 & -.546 \\
\hline a1 & 1.000 & 5.000 & -.585 & -3.259 & -.298 & -.830 \\
\hline s6 & 2.000 & 5.000 & -.646 & -3.594 & -.450 & -1.252 \\
\hline s5 & 1.000 & 5.000 & -.768 & -4.275 & -.111 & -.310 \\
\hline s4 & 1.000 & 5.000 & -.467 & -2.598 & -.686 & -1.910 \\
\hline s3 & 1.000 & 5.000 & -.661 & -3.680 & .143 & .398 \\
\hline s2 & 1.000 & 5.000 & -.460 & -2.559 & .146 & .408 \\
\hline s1 & 1.000 & 5.000 & -.555 & -3.088 & -.114 & -.318 \\
\hline t8 & 1.000 & 5.000 & -.178 & -.989 & -.255 & -.710 \\
\hline t7 & 1.000 & 5.000 & -.639 & -3.557 & .105 & .292 \\
\hline t6 & 1.000 & 5.000 & -.800 & -4.452 & .316 & .880 \\
\hline t5 & 1.000 & 5.000 & -.914 & -5.089 & .647 & 1.801 \\
\hline t4 & 1.000 & 5.000 & -.295 & -1.640 & -.514 & -1.430 \\
\hline t3 & 1.000 & 5.000 & -.776 & -4.322 & .941 & 2.620 \\
\hline $\mathrm{t} 2$ & 1.000 & 5.000 & -.779 & -4.336 & .413 & 1.149 \\
\hline $\mathrm{t} 1$ & 1.000 & 5.000 & -1.004 & -5.589 & .908 & 2.528 \\
\hline Multivariate & & & & & 58.506 & 10.858 \\
\hline
\end{tabular}


The results of Table 1 indicate that the data were not normally distributed and therefore we remove some of the unusual numbers from the survey and repeat the calculation until we reach some normally distributed data. We have used structural equation modeling to verify the hypotheses of the survey and Fig. 2 shows the results of our findings.

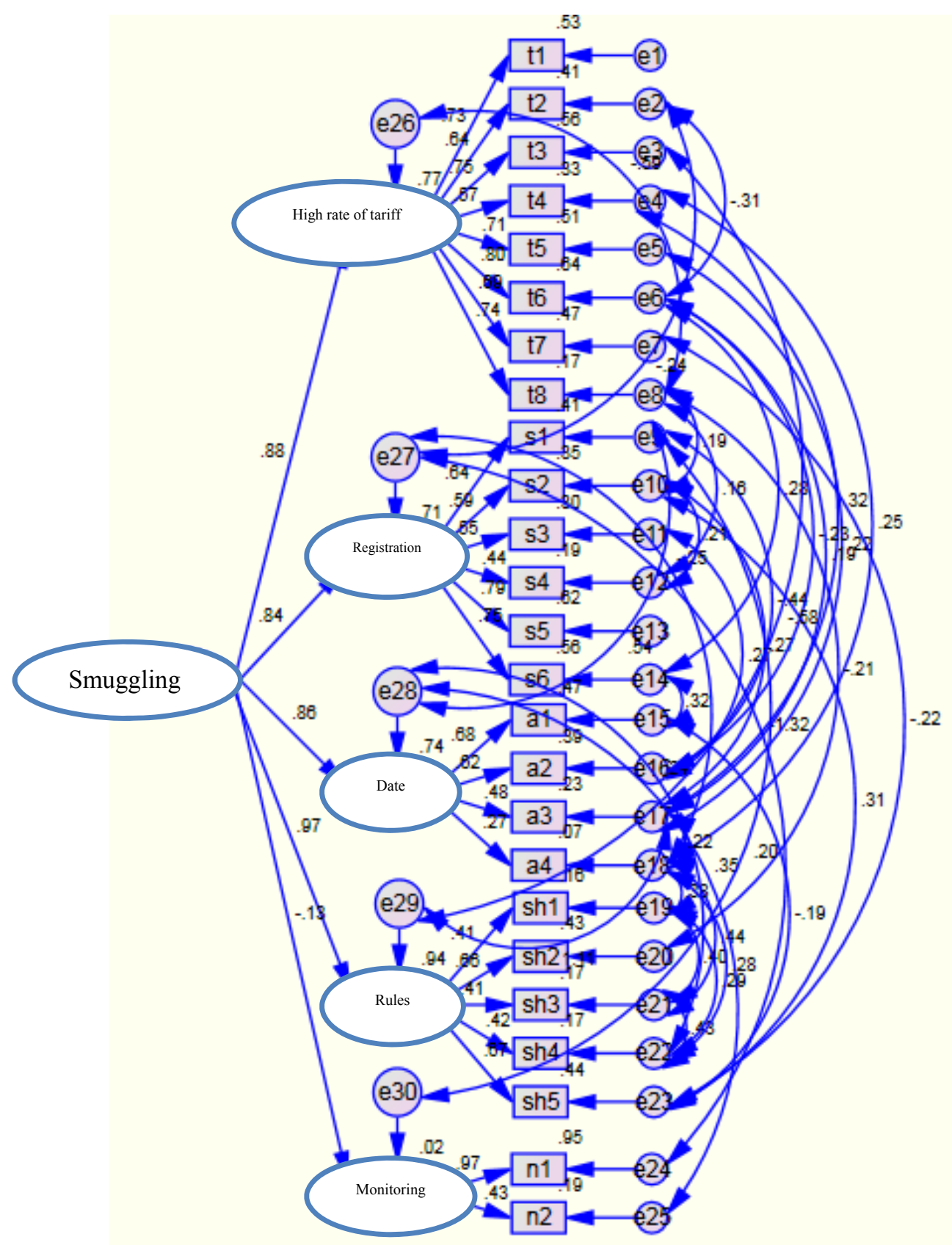

Fig. 2. The results of structural equation modeling in standard form

Investigating various statistical test such RMSEA, GFI, etc. have indicated that the results of structural equation modeling are valid. In addition, all statistical tests are meaningful when the level of significance is five percent.

\section{Discussion and conclusion}

The proposed study has applied structural equation modeling to study the effects of these five components. The results of Fig. 2 have indicated a positive and meaningful relationships between four variables including registration process $(\beta=0.84$, P-value $=0.000)$, size and expire date $(\beta=$ 0.86 , P-value $=0.000)$, high rate of tariff $(\beta=0.88, \mathrm{P}$-value $=0.000)$ and government recent 
regulation failure $(\beta=0.97$, P-value $=0.000)$ on growth of smuggling cosmetic products in Iran. In addition, the study has detected a negative and meaningful relationship between lack of accurate monitoring of distribution channels and growth of smuggling cosmetic products in Iran $(\beta=-0.18, \mathrm{P}$ value $=0.000)$. The results of our investigation are somewhat consistent with other similar results (Aasness \& Nygård, 2014). Gordoncillo et al. (2013) investigated the effect of anti-smuggling policies for selected agricultural commodities in the Philippines and reported that government rules and regulations could help reduce smugelling. Che and Benson (2014) for instance, emphasized that strict rules and regulations could reduce smuggling drugs. According to Grewcock (2014) and Nethery and Gordyn (2014) Australia's punitive border policing regime, targeted at deterring asylum seekers trying un-authorized entry into this country, was ratcheted up in 2013 by the former Laborled government and its successor, the Liberal National Party Coalition. Under the guise of fighting 'people-smuggling', and a pledge to 'Stop the Boats', policies such as the mandatory detention of unauthorized arrivals and the implementation of off-shore detention facilities have been made even more draconian.

\section{Acknowledgement}

The authors would like to thank the anonymous referees for constructive comments on earlier version of this paper.

\section{References}

Aasness, J., \& Nygård, O.E. (2014). Revenue functions and Dupuit curves for indirect taxes with cross-border shopping. International Tax and Public Finance, 21 (2), 272-297.

Benson, J. S., \& Decker, S. H. (2010). The organizational structure of international drug smuggling. Journal of Criminal Justice, 38(2), 130-138.

Bhagwati, J., \& Hansen, B. (1973). A theoretical analysis of smuggling. The Quarterly Journal of Economics, 87(2), 172-187.

Bruns, B., Miggelbrink, J., \& Müller, K. (2011). Smuggling and small-scale trade as part of informal economic practices: Empirical findings from the Eastern external EU border. International Journal of Sociology and Social Policy,31(11/12), 664-680.

Breuer, I., \& Kreuer, D. (2012). Market spaces in a globalising periphery: Livestock trade, borders, and liberalisation in eastern morocco. Economic Spaces of Pastoral Production and Commodity Systems: Markets and Livelihoods, 151.

Che, Y., Benson, B.L. (2014). Drug trafficking wars: Enforcement versus smugglers and smugglers versus smugglers. Journal of Drug Issues, 44(2), 150-179.

Decker, S. H., \& Chapman, M. T. (2008). Drug smugglers on drug smuggling. Philadelphie: Temple University Press.

Farzanegan, M. R. (2009). Illegal trade in the Iranian economy: Evidence from a structural model. European Journal of Political Economy, 25(4), 489-507.

Goel, R. K. (2012). Effect of generic cigarettes on US cigarette demand and smuggling. Economics Letters, 115(1), 114-117.

Gordoncillo, P.U., Quicoy, C.B., Delos Reyes, J.A., Vista, A.B. (2013). Effectiveness of antismuggling policies for selected agricultural commodities in the Philippines. Journal of the International Society for Southeast Asian Agricultural Sciences, 19 (1), 8-23.

Grewcock, M. (2014). Australian border policing: Regional 'solutions' and neocolonialism. Race and Class, 55(3), 71-78.

Hartnett, A., Dawdy, S.L. (2013). The archaeology of illegal and illicit economies. Annual Review of Anthropology, 42, 37-51.

Martin, L., \& Panagariya, A. (1984). Smuggling, trade, and price disparity: A crime-theoretic approach. Journal of International Economics, 17(3), 201-217. 
1152

Mountz, A. (2003). Human Smuggling, the Transnational Imaginary, and Everyday Geographies of the Nation-State. Antipode, 35(3), 622-644.

Mountz, A. (2004). Embodying the nation-state: Canada's response to human smuggling. Political geography, 23(3), 323-345.

Nethery, A., \& Gordyn, C. (2014). Australia-Indonesia cooperation on asylum-seekers: a case of 'incentivised policy transfer'. Australian Journal of International Affairs, 68 (2), 177-193

Xheneti, M., Smallbone, D., \& Welter, F. (2013). EU enlargement effects on cross-border informal entrepreneurial activities. European Urban and Regional Studies, 20(3), 314-328. 